\title{
THE INFLUENCE OF UTAUT FACTORS ON E-RETENTION WITH E-SATISFACTION AS MEDIATING VARIABLE IN E-LEARNING
}

\author{
Agustina, Priyanka. Indriati, Fibria \\ Department of Business Administration, Faculty of Administrative Sciences, Universitas Indonesia
}

\begin{abstract}
Factors on Unified Theory of Acceptance and Use of Technology (UTAUT) are factors derived from UTAUT technology acceptance model, which is used to describe the factors that influence the acceptance of individuals on the implementation of a new technology in the enterprise. This study aimed to analyze the influence of UTAUT factors on E-retention with E-satisfaction as mediating variable. This study uses a quantitative approach with the total samples. The results showed that: (1) Performance Expectancy influences E-retention significantly, (2) Effort Expectancy influences E-retention significantly, (3) Social Influence influences E-retention not significantly, (4) Facilitating Conditions influences E-retention significantly, (5) E-satisfaction influences E-retention significantly, and (6) UTAUT Factors influence E-retention with E-satisfaction as mediating variable. However, the bigger impact is shown through the influence of UTAUT Factors on E-retention directly without going through the E-satisfaction.
\end{abstract}

Keywords: E-learning; E-retention; E-satisfaction; Effort Expectancy; Facilitating Conditions; Performance Expectancy; Social Influence.

*) corresponding author 


\section{INTRODUCTION}

Internet or Interconnection Networking is not a new thing in the society. The information technology is growing rapidly (Indonesia Online Press Services, 2012). Nowadays, people begin to rely on internet information technology because they are increasingly heading towards efficiency, thus saving time and costs.

Based on the perspective of the learning system proposed Marquardt (1996) in Wan-Tzu Wong and Norman Neng-Tang Huang (2011), technology can be used as a basis for technology-based learning that contribute to the infrastructure and when it is used to support learning (learning) through the Internet, then can be called with e-learning technology. E-learning is a logical consequence of the development of internet technology. Rae (2000) said that e-learning has become a 'revolution' in the world's largest training and development in recent years.

Because it gives a lot of flexibility in the choice of place and time in learning, Fuji et .al (2004) in Imamoglu (2007) said that e-learning is self-learning, in which employees conduct themselves, neither someone can directly control the use of e-learning. Therefore, it is important for companies to focus on employee retention for e-learning called e-retention.

Retention often seen synonymous with loyalty (Al-Hawari, 2006: AlHawari and Ward, 2004 in Al-Hawari \& Mouakket 2010). This is evidenced by the presence of an agreement between the academic and practitioner, that retention and loyalty are two of the same thing (Maloles, 1997, in Al-Hawari \& Mouakket, 2010). Accordingly, this study see these two things as the same concept and term retention that will be used in this study.

To produce retention on e-learning needed the satisfaction called e-satisfaction. Kozak and Rimmington (2000) in Mechinda et. al (2009) said that satisfaction has a very important role on loyalty or retention because it affects a person's decision to use and return. For that, in general, positive satisfaction was found to influence retention (Nguyen and LeBlanc, 1998 in Al-Hawari and Mouakket, 2010).

One of suppliers of coal companies in Indonesia adopts e-learning as an employee training program. The company recently focuses on two modul of e-learning, which are Tell Me More dan Occupational Health and Safety. The research will focus on the program Tell Me More (TMM) as a program that has been running for a period that is 2011/2012. Based on the survey results of the evaluation of the company, there are factors that affect the use of e-learning on employees.

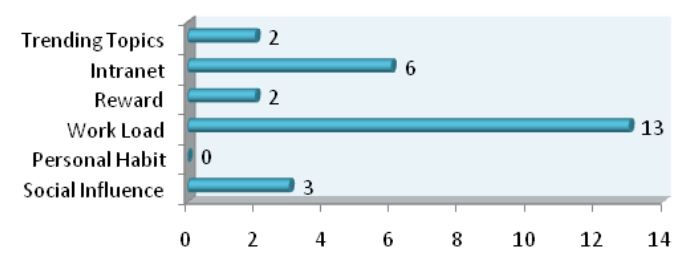

Figure 1. Factors Affecting the Use of E-learning Tell Me More (TMM) $(n=24)$

The survey results in Figure 1 demonstrate that technology such as e-learning that is intended to increase productivity, it must be accepted and used by the employees in the company (Venkatesh, et. al, 2003). Therefore, the need for an evaluation of the training (Decenzo \& Robbins, 2002) which became a stage where the company can see how well the results obtained through the training and whether the training methods used are the best methods to achieve the goals (Dessler, 2003). Companies need to decide how 
to determine the effectiveness of training programs by identifying the results of training or there are criteria to be measured (Noe, 2010).

This research will use models of Unified Theory of Acceptance and Use of Technology (UTAUT) to measure the implementation of e-learning which consist of four factors, such as performance expectancy (the belief that an individual has the better performance when using technology), effort expectancy (expectation ease of use of technology), social influence (influence others to use the technology), and facilitating conditions (infrastructure and technical support companies in the use of technology). The model introduced by Venkatesh et. al (2003) and considered to be more suitable for assessing of successful implementation of a new technology in organizations and has been validated in empirical studies (Lai and Chen, 2009; Min, Ji \& Qu, 2008; within Wan-Tzu Wong \& Norman Neng-Tang Huang 2011).

The things that want to be seen in this study are: (1) the influence of Performance Expectancy on E-retention, (2) the influence of Effort Expectancy on E-retention, (3) the influence of Social Influence on E-retention, (4) the influence of Facilitating Conditions on $\mathrm{E}$-retention, (5) the influence of E-satisfaction on E-retention, as well as, (6) the influence of Performance Expectancy, Effort Expectancy, Social influence, and Facilitating Conditions on the E-retention with E-satisfaction as mediating variable.

\section{THE ORETICAL FRAME WORK E-learning}

According to Mondy (2008), e-learning is the delivery of training and development system for online instruction. In this case, the "e" in e-learning refers to the electronic
(Barrow, 2003). E-learning, is defined by Davies (2001, p: 9) in Vaugan and MacVicar (2004), as the use of electronic multimedia technology used to provide education, information skills, knowledge and individual learning programs for large audiences, potentially around the world, with using the internet, intranet and other technology-based systems. Then, Rosenberg (2001) said that e-learning refers to the use of Internet technologies to provide solutions that improve knowledge and performance.

In its implementation, e-learning provides advantages compared to other training delivery systems. According to Noe (2010), e-learning is accessible anytime and anywhere, and training can be delivered to geographically dispersed employees at each location that will reduce travel costs associated with bringing the employees at the training location.

In addition to advantages, the application of e-learning also proved to have disadvantages. According to Rosenberg (2006), e-learning using information technology, so that not everyone, especially those who are new to use it well and also not all people want to use e-learning as a learning medium. In addition, because it is done online, E-learning have less motivation among employees. Access to use e-learning can be limited if the employee intranet access difficulties (Noe, 2010).

\section{Technology Acceptance Theory}

Technology Acceptance Model (TAM), which was introduced by Davis in 1989 , is the theory of the general acceptance of the technology used to predict the acceptance, adoption, and use of information systems (Halawi and McCarthy, 2007; within Al-Hawari and Mouakket, 2010). TAM explains the acceptance of information technology in performing their duties as well as two 
key determinants that increase the use of technology that identifies perceived usefulness (perceived of usefulness) and the perceived ease of use (perceived ease of use) (Wan-Tzu Wong \& Norman Neng-Tang Huang, 2011). Although the model is supported by empirical studies (Lee and Lee, 2008; Parka, Romanb, Leec, and Chungd, 2009; Roca et al., 2006), the critics doubted this model can only be used in an educational context (Ma, Andersson, Streith, 2005), and the neglect of social influence in technology acceptance (Chen, Gillensonb, \& Sherrell, 2002, in Wan-Tzu Wong \& Norman Neng-Tang Huang, 2011).

One of the theoretical models that can be used to overcome the weaknesses of TAM is the Unified Theory of Acceptance and Use of Technology (UTAUT). UTAUT is a theoretical model introduced by Venkatesh et. al in 2003. In concept, UTAUT describe the factors that influence an individual's acceptance of information technology by using related theory of psychology (psychology) and behavior (behavior), thus expanding the concept of TAM to fit the work environment (Wan-Tzu Wong \& Norman Neng-Tang Huang 2011). For that, model UTAUT considered more suitable, so it can be used to assess the successful implementation of a new technology and has been validated by empirical research (Lai and Chen, 2009; Min, Ji, \& Qu, 2008), in Wan-Tzu Wong \& NengNorman Tang Huang, 2011). UTAUT was developed through a study conducted on the acceptance of the theory of the eight models are widely used in the research of information.

Table 1.

IndividualsAcceptanceModeland theTheoryof theTechnology

\begin{tabular}{|c|c|c|}
\hline Model & Researcher & Concept \\
\hline $\begin{array}{l}\text { Theory of } \\
\text { Reasoned } \\
\text { Action (TRA) }\end{array}$ & $\begin{array}{l}\text { Fishbeindan Azjen } \\
\quad(1975)\end{array}$ & $\begin{array}{l}\text { Taken fromsocial psychology, TRA is one of the most } \\
\text { fundamental the oriesand influence on human behavior. This } \\
\text { model has been used to predicta variety of behaviors (Sheppard } \\
\text { et. Al, 1988). }\end{array}$ \\
\hline $\begin{array}{l}\text { Technology } \\
\text { Acceptance Model } \\
\text { (TAM) }\end{array}$ & Davis (1989) & $\begin{array}{l}\text { Designed to predict the accept anceand use of information tech- } \\
\text { nologyon work. }\end{array}$ \\
\hline $\begin{array}{l}\text { Motivational } \\
\text { Model (MM) }\end{array}$ & Davis et al. (1992) & $\begin{array}{l}\text { Theory of motivation developed to understand the adoption anduse of new } \\
\text { technologies. }\end{array}$ \\
\hline $\begin{array}{l}\text { Theory of Planned } \\
\text { Behavior (TPB) }\end{array}$ & Ajzen (1998) & $\begin{array}{l}\text { TPB extended TRA by adding the construct of perceived behavioral control. In } \\
\text { the TPB, perceived behavior alcontrol diteoribean additional determinant of } \\
\text { intention and behavior. }\end{array}$ \\
\hline $\begin{array}{l}\text { Combine TAM and } \\
\text { TPB (C-TAM-TPM) }\end{array}$ & $\begin{array}{l}\text { Taylor dan Todd } \\
\quad \text { (1995) }\end{array}$ & $\begin{array}{l}\text { a combination of TPB with perceived useful ness of TAM to support a hybrid } \\
\text { model. }\end{array}$ \\
\hline $\begin{array}{c}\text { Model of PC } \\
\text { Utilization (MPCU) }\end{array}$ & $\begin{array}{l}\text { Thompson, et. al } \\
\text { (1991) }\end{array}$ & $\begin{array}{l}\text { The development of Triand is Theory of Human Behavior and refined adapted } \\
\text { to the context of information systems. This model is used to predict PC utiliza- } \\
\text { tion. }\end{array}$ \\
\hline $\begin{array}{l}\text { Innovation Diffusion } \\
\text { Theory (IDT) }\end{array}$ & Rogers (1962) & $\begin{array}{l}\text { It has been used since } 1960 \text { to study a variety of innovations, ranging from ag- } \\
\text { ricultural tools to organizational innovation (Tornatzky \& Klein, 1982). Moore } \\
\text { and Benbasat (1991) and then adopt the innovation characteristics and refine a } \\
\text { set of constructs that can be used to study the acceptance of the technology. }\end{array}$ \\
\hline $\begin{array}{l}\text { Social Cognitive } \\
\text { Theory (SCT) }\end{array}$ & Bandura (1977) & $\begin{array}{l}\text { Understanding human behavior in order to determine the user accept an cean- } \\
\text { dusage of information technology in general. }\end{array}$ \\
\hline
\end{tabular}

Source: Venkatesh et .al (2003) 
Based on a review of the eight theoretical models, Venkatesh et. al (2003) suggested four theoretical ideas which will play an important role as a factor directly affecting the user acceptance and usage behavior. Furthermore, in this study, this research did not use the UTAUT model as a whole. This study will only focus on the factors that directly affect user acceptance and usage behavior of technology, such as:

Performance Expectancy, defined as the extent to which the level of expectations for each individual that will use technology systems to help the users to be able to improve performance

Effort Expectancy, defined as the extent to which the expectations of an individual who owned the ease of use of technology. Effort Expectancy constructs in each model is significant, both in the context of the use of voluntary and mandatory. However, the significant only during the first period, and being no longer significant during periods of extended use and sustainable.

Social Influence defined as the extent to which an individual feels that the importance of the belief that an individual must use the technology. Venkatesh and Davis (2000) in Venkatesh et. al (2003) said that the use in the context of mandatory compliance will lead to social influence has a direct effect on intention

Facilitating Conditions, defined as the level of confidence that the individual organization and technical infrastructure available to support the use of technology.

\section{E-satisfaction}

According to Jamal and Naser (2003, in Al-Hawari \& Mouakket, 2010), satisfaction is marketing the land is generally defined as a feeling or consideration from the consumer to the product or service after consumer use. In the context of the electronic satisfaction, e-satisfaction emerged as a term. Electronic satisfaction according to Lee (2001: p.75; within Teimouri and Kazemi, 2012) is a customer satisfaction level of support to receive and send orders goods or services, after sales service, the price of goods and services, the quality of the website content, site speed, reliability site, ease of use of the site, and the site as well as the financial security of personal privacy. Meanwhile, Oliver (1989: p. 29) in Teimouri and Kazemi (2012) says Electronic satisfaction is customer satisfaction with the level of web design as well as comfort and security purchases.

In addition, Szymanski and Hise (2000) Sahadev and Purani (2008) saw that e-satisfaction as a judgment on the overall online experience for a specific time period. Then, loyalty or retention of the e-learning is considered as a result of satisfaction with e-learning (Sahadev and Purani, 2008). Satisfaction has a very important role on loyalty or retention because it affects a person's decision to choose a destination and choose to return. If they are satisfied, they will be more likely to use e-learning again. For that, in general, positive satisfaction was found to influence retention (Nguyen and LeBlanc, 1998 in Al-Hawari \& Mouakket, 2010).

\section{E-retention}

Retention is similiar as loyalty (AlHawari, 2006, Al-Hawari and Ward, 2004, in Al-Hawari \& Mouakket, 2010). In this case, it seems there is a consensus among the academic and practitioner, that retention and loyalty are two of the same thing (Maloles, 1997 in Al-Hawari \& Mouakket, 2010). Therefore, this study will treat both as the same thing. For these reasons, researchers will use the term e-retention in describing the retention of e-learning. The same is done by Al-Hawari \& Mouakket (2010).

Oliver (1997) describes the loyalty or retention as a deep commitment to 
making a purchase or a repeat visit to a selected product or service consistently in the future, which will lead to repeat purchase the same brand or product line of the same brand, although there are significant marketing and business situations that could potentially lead to behavior change.

In addition to re-purchase, according to Griffin (2005), loyal customers will refer or recommend the products that they consume to others, so that other people want to use. Not only that, according to Zeithaml (1996) in Sahadev and Purani (2008), consumers with greater loyalty would do things like put out positive words related manufacturers and products (positive word of mouth). Furthermore, customer loyalty can be expressed in behavior. This behavior can be manifested in the great desire to maintain the relationship, such as the tendency for complaints and constructive criticism or even words that express a positive willingness to join with providers of consumer choice of goods or services (cristou, 2001 in Ltifi, 2012). Refers to a journal written by Al-Hawari \& Mouakket (2010), e-retention in this study can be defined as the extent to which users indicate behavior over and over to e-learning, and have a cognitive disposition and positive attitude.

\section{RESEARCH METHODS}

This study uses a quantitative approach. By design, this study included in the explanatory research aimed at explaining how a social phenomenon happening by testing for a prediction of the theory or principle and examine the relationship between variables. Then viewed from the benefits, the study categorized in applied research as addressed directly to solve problems and produce recommendations for specific problems (Neuman, 1994).

Then, the data collection techniques are divided into two, such as: (1) the study of literature through books, internet, journals, and review of the literature on several previous studies and secondary data from companies associated with e-learning, and (2) a field study using questionnaires and in-depth interviews to support the questionnaire data were conducted on learning administration and staff employees who became participants and users of e-learning. Rating scales used in the research instrument Likert scale that is widely used and is commonly used in survey research (Neuman, 1994). This scale indesign to examine how strongly subjects agree or disagree with the statement in the 5 scale very strongly disagree, disagree, not agree or disagree (neutral), agree and strongly agree (Sekaran, 2011).

In this study, the samples used by researchers is the total sampling, which covers all employees who join the e-learning for the period 2011/2012. It was 84 employees. With this sampling method is expected the results can be more likely to approach the real value and can also reduce the occurrence of errors or deviations from the population value (Usman and Akbar, 2006). Jakarta Elections Office is based on several considerations such as: (1) technical issues related internet system at the site is less support, (2) site is still a lot of employees who access the Internet through a Personal Computer (PC) in which the intranet connection is harder to come by than when using laptop, (3) the practical problems because of access to the site is not possible, and (4) time efficiency in research. 


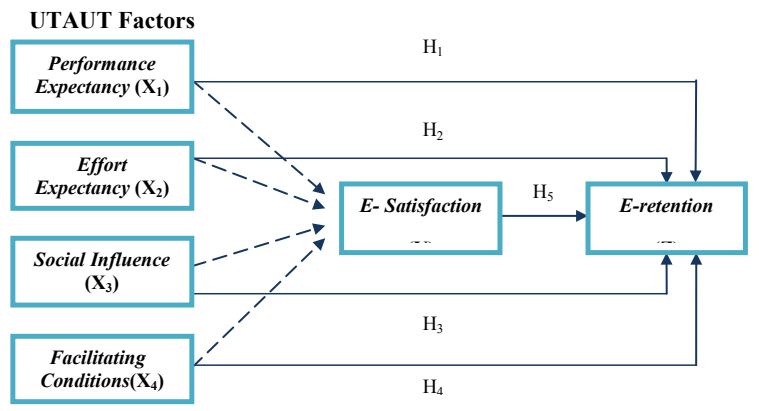

Figure 2. Research Model

Past research has shown that there are several factors that affect the user directly or indirectly in the use of e-learning. According to the research Jiinpo $\mathrm{Wu}$ (2006), there are several factors that influence Information Systems Continuance Intention as Computer Self Efficacy on the e-learning user, Perceived Usefulness, Confirmation, and Satisfaction levels. While the study results Imamoglu (2007) stated intention to use, ability to use and commitment play a role as a mediator between the perceived ease of use and perceived usefulness of the e-learning. Later in the study Packham (2004) also stated there are intrinsic and extrinsic barriers affecting students interested in e-learning. Lastly, research Ya-Ching Lee (2006) showed a direct effect or indirectly derived acceptance factors in adopting E-learning System. In this study, researchers used the factors of the technology acceptance model of Venkatesh et. al (2003) Unified Theory of Acceptanceand Use of Technology (UTAUT) which will affect e-retention.

H1:Performance Expectancy influences E-retention significantly;

$\mathrm{H} 2$ :Expectancy influences E-retention significantly;

$\mathrm{H}_{3}$ :Social Influence influences E-retention not significantly; and, $\mathrm{H} 4$ :Facilitating Conditions influences E-retention significantly.

Many studies insvestigate the relationship between satisfaction and retention levels in a variety of different industries (Ranaweera and Prabhu,
2003, in Al-Hawari and Mouakket, 2010). Ribbink et. al (2004) says that e-loyalty in general is associated with e-satisfaction. It is also supported by the results of research that says that e-satisfaction affects e-loyalty is positively and significantly. In addition, research and Mouakket Al-Hawari (2010) showed that E-satisfaction is also one important factor in determining the level of E-retention and in turn have a significant influence on one factor TAM, namely ease of use, the e-retention .

$\mathrm{H}_{5}$ :E-satisfaction influences E-retention significantly; and,

H6:UTAUT Factors influence E-retention with E-satisfaction as mediating variable.

Table 2.

The Measurement Items

\begin{tabular}{|c|c|c|}
\hline Variable & Indicator & Scale \\
\hline $\begin{array}{c}\text { Performance } \\
\text { Expectancy } \\
\text { (Venkatesh, } \\
\text { et. al, 2OO3) }\end{array}$ & $\begin{array}{l}\text { - I would find the e-learning useful in } \\
\text { my job (PE1) } \\
\text { Using the e-learning enables me } \\
\text { to accomplish tasks more quickly } \\
\text { (PE2) } \\
\text { - Using the e-learning increases my } \\
\text { productivity (PE3) } \\
\text { If I use the e-learning, I will } \\
\text { increase my chances of getting a } \\
\text { raise (PE4) }\end{array}$ & $\begin{array}{l}\text { Interval } \\
\text { Interval } \\
\text { Interval } \\
\text { Interval }\end{array}$ \\
\hline $\begin{array}{c}\text { Effort } \\
\text { Expectancy (EE) } \\
\text { (Venkatesh, et. } \\
\text { al, 2003) }\end{array}$ & $\begin{array}{l}\text { My interection with the e-learning } \\
\text { would be clear and understandable } \\
\text { (EE1 and EE2) } \\
\text { It would be easy for me to become } \\
\text { skillful at using the e-learning } \\
\text { (EE3) } \\
\text { - I would find the e-learning easy to } \\
\text { use (EE4) } \\
\text { Learning to operate the e-learning } \\
\text { is easy for me (EE5) }\end{array}$ & $\begin{array}{l}\text { Interval } \\
\text { Interval } \\
\text { Interval } \\
\text { Interval }\end{array}$ \\
\hline $\begin{array}{l}\text { Social Influence } \\
\text { (SI) (Venkatesh, } \\
\text { et. al, 2003) }\end{array}$ & $\begin{array}{l}\text { People who influence ny behavior } \\
\text { think that I should use the e-learn- } \\
\text { ing (SI1) } \\
\text { People who are important to me } \\
\text { think that I should use the e-learn- } \\
\text { ing (SI2) } \\
\text { The senior management of this } \\
\text { business has been helpful in the use } \\
\text { of the e-learning (SI3) } \\
\text { In general, the organization has } \\
\text { supported the use of the e-learning } \\
(\mathrm{SI} 4)^{*}\end{array}$ & $\begin{array}{l}\text { Interval } \\
\text { Interval } \\
\text { Interval } \\
\text { Interval }\end{array}$ \\
\hline
\end{tabular}




\begin{tabular}{|c|c|c|}
\hline $\begin{array}{c}\text { Facilitating } \\
\text { Conditions (FC) } \\
\text { (Venkatesh, et. } \\
\text { al, 2003) }\end{array}$ & $\begin{array}{l}\text { I have the knowledges necessary to } \\
\text { use the e-learning (FC1) } \\
\text { The e-learning is compatible with } \\
\text { other technology I use (FC2 dan } \\
\text { FC3) } \\
\text { I have the resources necessary to } \\
\text { use the e-learning (FC4,FC5, dan } \\
\text { FC6) } \\
\text { A specific person (or group) is } \\
\text { available for assistance with } \\
\text { e-learning difficulties (FC7, FC8, } \\
\left.\text { dan } \mathrm{FC}_{9}\right)^{*}\end{array}$ & $\begin{array}{l}\text { Interval } \\
\text { Interval } \\
\text { Interval } \\
\text { Interval }\end{array}$ \\
\hline $\begin{array}{c}\text { E-satisfaction } \\
\text { (Ribbink et al., } \\
\text { 2004; Sahadev } \\
\text { dan Purani, 2008; } \\
\text { in Al-hawari ¿ } \\
\text { Mouakket, 2010) }\end{array}$ & $\begin{array}{l}\text { I am satisfied with services offered } \\
\text { by e-learning (E-satisfaction1) } \\
\text { I am satisfied with designs and } \\
\text { fitures offered by e-learning (E-sat- } \\
\text { isfaction2 and E-satisfaction3) } \\
\text { - } \quad \begin{array}{l}\text { I am satisfied with usefulness } \\
\text { offered by e-learning (E-satisfac- }\end{array} \\
\text { tion4) } \\
\text { I am satisfied with enjoyment } \\
\text { offered by e-learning (E-satisfac- } \\
\text { tion5) } \\
\text { I am satisfied with ease of using } \\
\text { e-learning (E-satisfaction6) }\end{array}$ & $\begin{array}{l}\text { Interval } \\
\text { Interval } \\
\text { Interval } \\
\text { Interval } \\
\text { Interval }\end{array}$ \\
\hline $\begin{array}{c}\text { E-retention } \\
\text { (Zeithaml et al., } \\
\text { 2006; Ribbink } \\
\text { et al., 2004; Cry } \\
\text { et al., 2006; in } \\
\text { Al-hawari \& } \\
\text { Mouakket, 2010) }\end{array}$ & 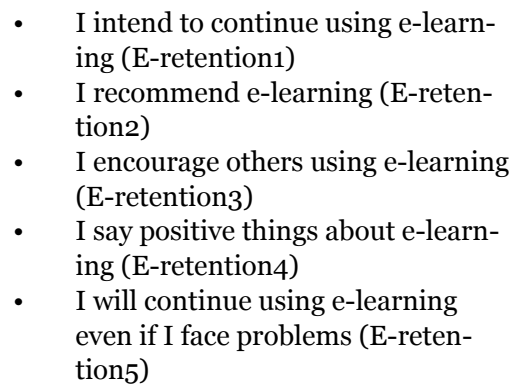 & $\begin{array}{l}\text { Interval } \\
\text { Interval } \\
\text { Interval } \\
\text { Interval } \\
\text { Interval }\end{array}$ \\
\hline
\end{tabular}

Note: * Item deleted in the validity tes

Data analysis was performed using simple regression to see the effect of each independent variable, namely Performance Expectancy; Effort Expectancy; Social Influence, and Facilitating Conditions on the dependent variable retention as well as the influence of E-satisfaction to E-retention. Then also used multiple regression to see the effect of the independent variables that Performance Expectancy; Effort Expectancy; Social Influence, and Facilitating Conditions together the variables between E-satisfaction and the last used path analysis (path analysis) to determine how the influence of each variable (De Vaus, 1996), using SPSS 17.0.

To test the hypothesis, the simple regression, it will use the t test to look at the significance value in the table variable coefficient test, while the significance of the regression test will be used to look at the value of the $\mathrm{F}$ test of significance in the ANOVA table. Significance values are allowed to answer the primary hypothesis is 0.05. If the significance value is below 0.05, then Ho is rejected and $\mathrm{Ha}$ accepted. And then, if the significance value is above 0.05 , Ho is accepted and Ha rejected.

\section{RESULTS}

\section{Characteristics of the respondents}

From 84 respondents, a total of 9 employees had resigned from the company, 3 employees moving to another site and an employee who was on leave. Thus the study sample was 71 employees. Of the 71 questionnaires distributed to the employees of e-learning users, questionnaires returned entirely by the same amount. However, after the test the validity, of the 71 respondents who completed questionnaires, only 62 questionnaires which the data is valid and can be used in this research.

Characteristics of the respondents are divided into six categories, namely gender, age, education level, occupation, long service life and using e-learning. Based on survey data, $53.2 \%$ of respondents sex men and women as much as $46.8 \%$. In terms of age, $30.6 \%$ were aged 24-31 years, 40.4\% aged 3238 years and $29 \%$ aged $39-50$ years. Of 62 respondents, the most dominant education level is equal $\mathrm{S} 1$ and most respondents as a supervisor position. Based on working time, an average of $53.2 \%$ of respondents have working time $>5$ years and the remaining $46.8 \%$ has working time of between 1-5 years. And then, from 62 respondents who answered the question about the duration of use of e-learning, one respondent did not answer. The most respondents used 
e-learning $<3$ months $(36.10 \%)$. Then, $21.30 \%$ of respondents use the 3-6 month and $26.20 \%$ of respondents using e-learning $>6$ and has reached one year. Meanwhile, respondents who use e-learning > 1 year just are $16.40 \%$.

\section{Validity and Reliability Test}

In this study, the measurement validity by analyzing factors through the pre-test questionnaire to see the value of Kaiser-Meyer-Olkin Measure of Sampling Adequacy, Bartlett's Test of Sphericity, Anti-Image Matrices, and Component Matrix (Hair et. Al, 2010). Bersadarkan validity of the test results, an indicator variable with the question of Social Influence should be removed because it is based on the anti-image correlation was $<0.5$ and an indicator with three questions of Facilitating Conditions should be removed because it is invalid based component matrix.

After the test the validity, reliability test is then performed. Reliability test was used to test the consistency and accuracy of measurement questionnaire (Hair et. al , 2010). According to Sekaran (2011), reliability coefficients approaching 1 is the most excellent. In general, if the alpha coefficient was below 0.6 then shows poor reliability, number around 0,7 indicates acceptable reliability and coefficient alpha is above 0.8 indicates good reliability. Reliability test results of each of the variables showed that all study variables are reliable. This is evidenced by the large Croanbach's Alpha values that are $>0,6$ (Sekaran, 2011). Facilitating Conditions variable rated acceptable because the value is around 0,7 , while Performance Expectancy, Effort Expectancy, Social Influence, E-satisfaction and E-retention has good reliability because its value is more than 0,8 .

\section{Descriptive Statistics Analysis}

Discussion of descriptive statistics per variable is done by analyze the mean of respondents' answers to identify trends that lead to the approval and disapproval. Table 3 shows the mean of each of the questions in the questionnaire study with class categories, where $4.20 \leq x<5.00$ (very high), $3.40 \leq \mathrm{x}<4.20$ (high), 2.60 $\leq \mathrm{X}<3.40$ (quite high), $1.80 \leq \mathrm{x}<2.60$ (low), and $1.00 \leq x<1.80$ (very low).

Table 3.

Mean of Variable

\begin{tabular}{|c|c|c|c|}
\hline \multicolumn{2}{|r|}{ Indicator } & \multirow{2}{*}{$\begin{array}{c}\text { Mean } \\
3,16 \\
\end{array}$} & \multirow{2}{*}{$\begin{array}{c}\text { Category } \\
\text { Quite high }\end{array}$} \\
\hline Perform & Expetancy (PE) & & \\
\hline PE1 & E-learning is useful for my work in the company & 3,50 & high \\
\hline PE2 & By using e-learning, I able to complete my job quickly & 2,89 & Quite high \\
\hline$P E 3$ & Using the e-learning increases my productivity & 2,95 & Quite high \\
\hline$P E_{4}$ & If I use the e-learning, I will increase my chances of getting a raise & 3,26 & Quite high \\
\hline \multicolumn{2}{|c|}{ Effort Expectancy $(E E)$} & 3,27 & Quite high \\
\hline EE1 & My interection with the e-learning would be clear & 3,15 & Quite high \\
\hline EE2 & My interection with the e-learning would be understandable & 3,27 & Quite high \\
\hline EE3 & It would be easy for me to become skillful at using the e-learning & 3,23 & Quite high \\
\hline EE4 & I find the e-learning easy to use & 3,32 & Quite high \\
\hline EE5 & Learning to operate the e-learning is easy for me & 3,39 & Quite high \\
\hline \multicolumn{2}{|c|}{ Social Influence (SI) } & 2,73 & Quite high \\
\hline SI1 & People who influence ny behavior think that I should use the e-learning & 2,76 & Quite high \\
\hline SI2 & People who are important to me think that I should use the e-learning & 2,84 & Quite high \\
\hline $\mathrm{S} 13$ & $\begin{array}{l}\text { The senior management of this business has been helpful in the use of the } \\
\text { e-learning. }\end{array}$ & 2,58 & Low \\
\hline
\end{tabular}




\section{Agustina, Priyanka. Indriati, Fibria}

\begin{tabular}{|c|c|c|c|}
\hline \multicolumn{2}{|r|}{ Facilitating Conditions (FC) } & \multirow{2}{*}{$\begin{array}{l}3,45 \\
3,50\end{array}$} & \multirow{2}{*}{$\begin{array}{l}\text { Support } \\
\text { Support }\end{array}$} \\
\hline $\mathrm{FC} 1$ & I have the knowledges necessary to use the e-learning & & \\
\hline $\mathrm{FC} 2$ & The e-learning is compatible with computer or laptop I use & 3,66 & Support \\
\hline $\mathrm{FC} 3$ & The e-learning is compatible with internet connection I use & 3,50 & Support \\
\hline $\mathrm{FC} 4$ & The headsetsupportingtheuse ofe-learning & 3,68 & Support \\
\hline $\mathrm{FC}_{5}$ & The instructionsto the use ofe-learning are availablewell & 3,34 & $\begin{array}{l}\text { Quite Sup- } \\
\text { port }\end{array}$ \\
\hline FC6 & The environmentsupports me for usinge-learning & 3,00 & $\begin{array}{l}\text { Quite Sup- } \\
\text { port }\end{array}$ \\
\hline E-satisfaction & & 3,29 & Quite high \\
\hline E-satisfaction 1 & I am satisfied with services offered by e-learning & 3,21 & Quite high \\
\hline E-satisfaction 2 & I am satisfied with designs and fitures offered by e-learning & 3,27 & Quite high \\
\hline E-satisfaction 3 & I am satisfied with usefulness offered by e-learning & 3,32 & Quite high \\
\hline E-satisfaction 4 & I am satisfied with enjoyment offered by e-learning & 3,32 & Quite high \\
\hline E-satisfaction 5 & I am satisfied with ease of using e-learning & 3,34 & Quite high \\
\hline E-satisfaction 6 & I am satisfied with services offered by e-learning & 3,27 & Quite high \\
\hline E-retention & & 3,25 & Quite high \\
\hline E-retention 1 & I intend to continue using e-learning & 3,11 & Quite high \\
\hline E-retention 2 & I recommend e-learning & 3,34 & Quite high \\
\hline E-retention 3 & I encourage others using e-learning & 3,28 & Quite high \\
\hline E-retention 4 & I say positive things about e-learning & 3,45 & high \\
\hline E-retention 5 & I will continue using e-learning & 3,05 & Quite high \\
\hline
\end{tabular}

\section{Regression Analysis}

each factor on E-retention UTAUT with This study examines the influence of E-satisfaction as an intermediate variable.

Table 4.

Regression Results

\begin{tabular}{|c|c|c|c|c|c|}
\hline \multicolumn{2}{|c|}{ Influencebetween Variables } & Standardized Coefficients & \multicolumn{2}{|c|}{ Significance (t) } & Significant \\
\hline \multicolumn{2}{|c|}{ Performance Expectancy on E-retention } & 0,650 & \multicolumn{2}{|c|}{ o,ooo } & Significant \\
\hline \multicolumn{2}{|c|}{ Effort Expectancy on E-retention } & 0,548 & \multicolumn{2}{|c|}{ o,ooo } & Significant \\
\hline \multicolumn{2}{|c|}{ Social Influence on E-retention } & 0,152 & \multicolumn{2}{|c|}{0,240} & Not significant \\
\hline \multicolumn{2}{|c|}{ Facilitating Conditions on E-retention } & 0,519 & \multicolumn{2}{|c|}{0,000} & Significant \\
\hline \multicolumn{2}{|c|}{ E-satisfactiononE-retention } & 0,609 & \multicolumn{2}{|c|}{0,000} & Significant \\
\hline \multirow{2}{*}{\multicolumn{2}{|c|}{ Influence between Variables }} & \multirow{2}{*}{ Standardized Coefficients } & \multicolumn{2}{|c|}{ Significance } & Sionificant \\
\hline & & & $\mathrm{F}$ & $\mathrm{T}$ & Signimitant \\
\hline \multirow{4}{*}{$\begin{array}{c}\text { Influence Performance } \\
\text { Expectancy, Effort Expectancy, } \\
\text { Social Influence, Facilitating } \\
\text { Conditions on E-satisfaction }\end{array}$} & $\begin{array}{c}\text { Performance Expectancy on } \\
\text { E-Satisfaction }\end{array}$ & 0,156 & 0,000 & 0,182 & Not significant \\
\hline & $\begin{array}{l}\text { Effort Expectancy on } \\
\text { E-satisfaction }\end{array}$ & 0,197 & & 0,136 & Not significant \\
\hline & $\begin{array}{l}\text { Social Influence on } \\
\text { E-satisfaction }\end{array}$ & 0,097 & & 0,370 & Not significant \\
\hline & $\begin{array}{l}\text { Facilitating Conditions on } \\
\text { E-satisfaction }\end{array}$ & 0,390 & & 0,003 & Significant \\
\hline
\end{tabular}

Table 4 shows the final results and the significance of relationships between variables. This also shows that indeed there are factors that affect the use of e-learning, which in turn also influence a person's decision to continuous in use. 
The final results showed when they see the effect directly to the E-retention, the variables that most influence is the Performance Expectancy. Performance Expectancy is the most powerful factor in influencing E-retention compared with other factors UTAUT (Venkatesh et. al, 2003). Venkatesh et. al (2003) argue that Performance Expectancy is the strongest predictor in each individual technology acceptance model earlier. As Learning Administration staff said the company, that e-learning is expected to help the employees to be able to communicate in English fluently and also clear, especially for those who are dealing with expatriates (Results of in-depth interviews with staff learning administration, 2013). Therefore, employees with job position or job description feel certain e-learning benefit. However, the respondents said they felt the benefits of e-learning is limited to the capacity building and the development of knowledge, but not direct and significant impact on the job (Results of in-depth interviews with users of e-learning, 2013). Staff Learning Administration added that the factor of interest, needs and priorities in the last one will make them use of e-learning.

Effort Expectancy also contributed in determining the level of employee retention in using e-learning. According to Rosenberg (2006), not all people, especially those who still lay in the use of e-learning to use it well. In this case, some employees want to e-learning made in dual language because when they find difficulty in understanding the material and do not understand the language in the instructions, the employee will be diligent tend not to use. In addition to using the cloud, there are employees who do not want to use e-learning as a media of learning (Rosenberg, 2006).

Different from Performance Expectancy and Effort Expectancy, according to Venkatesh et. al (2003),
Social Influence is not significant in the context of voluntary use. This is because Social Influence does not affect the intention to use e-learning directly. According to Staff Learning Administration, notall employers support their employees in the use of e-learning. This is becausetheemployeeis considered to be not working and e-learning are not considered directly related to completing the work. In addition, it is recognized by the respondents in-depth interviews, that co-worker does not affect the use of e-learning. In this case a fellow employee does not seek to influence or be influenced by his friends. Noe (2010) said that one of the shortcomings of e-learning is the lack of motivation among employees to perform online learning, so that the use of e-learning among employees does not guarantee it will affect each other.

Facilitating Conditions also contributed in influencing employee retention rates for e-learning. Based on the results of in-depth interviews with staff Learning Administration (2013), said that the infrastructure is external factors that affect an employee in the use of e-learning. In this case, the employee is still experiencing limitations in taking the time and place because of the flexibility of e-learning can not be accessed outside of the office. Moreover, according to Noe (2010), the use of e-learning could be limited due to difficulties in employee intranet access.

This study also proved that the satisfaction of (e-satisfaction) can indeed affect the retention of a person in the use of e-learning. Szymanski and Hise (2000) say that E-satisfaction as a judgment on the overall online experience for a certain period of time (Sahadev and Purani, 2008). On the basis of this addition, employee satisfaction is not only determined by aspects of the measurement indicators used by researchers. Experiences related 
to service, design and features, usability and comfort in using e-learning has been shown to affect the retention of an employee in the use of e-learning.

\section{Path Analysis}

To determine the effect of Performance Expenctancy; Effort Expentancy; Social Influence, and Facilitating Conditions, E-satisfaction as mediating variable, and E-retention as the dependent variable, we used path analysis.

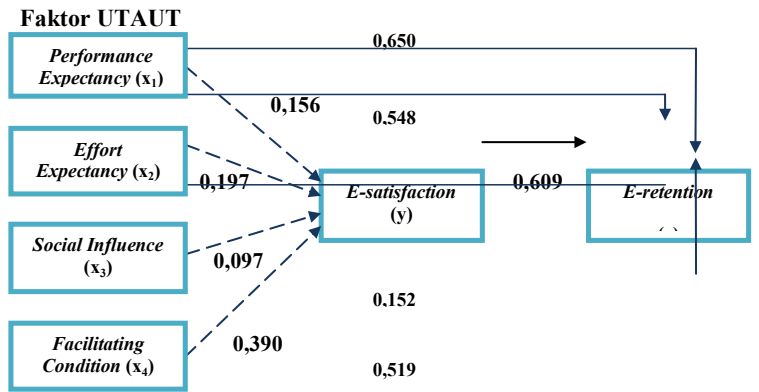

Based on these images, substruktural formed are:

$$
\begin{aligned}
& \text { Subsutruktural 1: } \\
& \mathrm{Y}=\mathrm{rX} 1 \mathrm{YX} 1+\mathrm{rX} 2 \mathrm{YX} 2+\mathrm{rX}_{3} \mathrm{YX}_{3}+ \\
& \mathrm{rX}_{4} \mathrm{YX}_{4}+\varepsilon 1 \\
& =0,156 \mathrm{X} 1+0,197 \mathrm{X} 2+0,097 \mathrm{X}_{3}+ \\
& 0,390 X 4+\varepsilon 1 \\
& \text { WW } \\
& \text { Subsutruktural 2: } \\
& \mathrm{Z}=\mathrm{rX} 1 \mathrm{ZX} 1+\mathrm{rX} 2 \mathrm{ZX} 2+\mathrm{rX}_{3} \mathrm{ZX}_{3}+ \\
& \mathrm{rX} 4 \mathrm{ZX} 4+\mathrm{rYZY}+\mu 2 \\
& =0,650 \mathrm{X} 1+0,548 \mathrm{X} 2+0,152 \mathrm{X} 3+ \\
& 0,519 \mathrm{X} 4+0,609 \mathrm{Y}+\mu 2
\end{aligned}
$$

Based on the model substruktural 1, the influence UTAUT factors on E-satisfaction only direct influence.

Table 5 .

Direct Influence of UTAUT Factors on E-satisfaction

Direct Influence Calculation Total

X1 langsung $(\rho \mathrm{X} 1 \mathrm{Y}) \times(\rho \mathrm{X} 1 \mathrm{Y}) \quad(0,156)(0,156) \quad 0,0243$

X2 langsung $(\rho \mathrm{X} 2 \mathrm{Y}) \times(\rho \mathrm{XY}) \quad(0,197)(0,197) \quad 0,0388$

$\mathrm{X}_{3}$ langsung $\left(\rho \mathrm{X}_{3} \mathrm{Y}\right) \times\left(\rho \mathrm{X}_{3} \mathrm{Y}\right)(\mathrm{o}, 097)(0,097) 0,0094$ $\mathrm{X}_{4}$ langsung $(\rho \mathrm{X} 4 \mathrm{Y}) \times(\rho \mathrm{X} 4 \mathrm{Y})(0,390)(0,390) \quad 0,1521$ Total Influence of X1, X2, X3 and X4on Y o,2246
Influence UTAUT factors (X1, X2, $\mathrm{X}_{3}$ and $\mathrm{X}_{4}$ ) to the E-satisfaction is at 0.2246 or $22.46 \%$. While $77.54 \%$ can be influenced by other aspects. UTAUT factors that most affect e-satisfaction is Facilitating Conditions least influence is from Social Influence where the employee works. That is, in this study, Facilitating Conditions influence the

\begin{tabular}{|c|c|c|c|c|}
\hline Variable & Influence & Calculation & R2 & Total \\
\hline $\begin{array}{c}\text { Performance } \\
\text { Expectancy } \\
(\mathrm{X} 1)\end{array}$ & $\begin{array}{l}\text { Directly } \\
\text { Not directly }\end{array}$ & $\begin{array}{c}0,650 \\
(0,156)(0,609) \\
=0,0950\end{array}$ & $(0,7450) 2$ & 0,5550 \\
\hline $\begin{array}{c}\text { Effort } \\
\text { Expectancy (X2) }\end{array}$ & Not directly & $\begin{array}{c}0,548 \\
(0,197)(0,609) \\
=0,1200\end{array}$ & $(0,6880) 2$ & 0,4462 \\
\hline $\begin{array}{l}\text { Social Influence } \\
\qquad\left(\mathrm{X}_{3}\right)\end{array}$ & $\begin{array}{l}\text { Directly } \\
\text { Not directly }\end{array}$ & $\begin{array}{c}0,152 \\
(0,097)(0,609)= \\
0,0591\end{array}$ & $(0,2111) 2$ & 0,0446 \\
\hline $\begin{array}{c}\text { Facilitating } \\
\left.\text { Conditions ( } \mathrm{X}_{4}\right)\end{array}$ & Not directly & $\begin{array}{c}0,519 \\
(0,390)(0,609)= \\
0,2375\end{array}$ & $(0,7565) 2$ & 0,5723 \\
\hline $\begin{array}{l}\text { E-satisfaction } \\
(\mathrm{Y})\end{array}$ & $\begin{array}{l}\text { Directly } \\
\text { Not directly }\end{array}$ & $\begin{array}{c}0,609 \\
-\end{array}$ & $(0,609) 2$ & 0,3709 \\
\hline
\end{tabular}
level of employee satisfaction, while has less contributing to Social Influence in influencing the level of employee satisfaction in the use of e-learning.

Furthermore, the researcher will explain the direct effect of each factor on E-retention UTAUT and indirect influence via E-satisfaction.

Table 6.

Total Influence of UTAUT Factors on E-retention

The total value of the coefficient of determination ( $\mathrm{R}$ Square) shows that by using path analysis model, the independent variables that Performance Expectancy (X1); Effort Expectancy (X2); Social Influence $\left(\mathrm{X}_{3}\right)$, and Facilitating Conditions (X4), have an influenced on the change of variables E-retention (Z) with E-satisfaction (Y) as mediating variable as much as 1,9890 or $198,90 \%$.

In the direct effect, Performance Expectancy has the greatest influence in comparison with other UTAUT factors. Whereas, when through E-satisfaction, Facilitating Conditions have indirect 
influence of the most large and well into the factors that most influence the overall employee retention in using e-learning, among other UTAUT factors. That is, Facilitating Conditions have satisfaction through first, and then lead to retention. In this case, the supporting facilities were affecting the level of satisfaction and ultimately affect employee retention rates.

The first interesting thing found in this study is the Performance Expectancy and Effort Expectancy has no significant effect on e-satisfaction, but has a significant influence on E-retention. That is, employees feel that the improved performance and ease of use of e-learning does not contribute to the increase in the level of satisfaction, but to be an important thing for those employees to be inherent and continuous in using e-learning. Further explanation, when employees feel that e-learning has provided increased performance, e-learning has become a necessity for employees, so that it directly affects the continuity in use. In addition, the employee already has a pretty good ability in using technology, so it is easy for employees to learn a new system anyway.

The next interesting thing found in this study is the direct effect of each factor UTAUT to E-retention was greater than when the indirect effect via E-satisfaction. That is, E-satisfaction is not a major factor for the employees in the embedding of e-learning and continuity in use.

\section{CONCLUSION}

Based on the research results, the results showed that: (1) Performance Expectancy influences E-retention significantly, (2) Effort Expectancy influences E-retention significantly, (3) Social Influence influences E-retention not significantly, (4) Facilitating
Conditions influences E-retention significantly, (5) E-satisfaction influences E-retention significantly, and (6) UTAUT Factors influence E-retention with E-satisfaction as an mediating variable. However, the bigger impact is shown through the influence of UTAUT Factors on E-retention directly without going through the E-satisfaction.

\section{RECOMMENDATION}

This research was conducted at the company's mining sector and is only done at Jakarta Office. Besides it is only aimed at one of the e-learning program within the company. Although this study provides information and understanding about the influence factor of the E-retention UTAUT with E-satisfaction as an intermediate variable, the results can not be generalized to all e-learning. Therefore, further research is expected to do so in other sectors with wider coverage.

\section{REFERENCES}

Al-hawari, M. Ahmad, \& Mouakket, Samar. (2010). "The Influence of Technology Acceptance Model (TAM) Factors on Students' E-satisfaction and E-retantion within the Context of UAE E-learning”. Emerald Group Publish Limited. Vol. 3 No. 4. pp 299-314.

Barrow, Colin. (2003). E-training and Development. United Kingdom: Capstone Publishing Limited.

De Vaus, D.A. (1996). Survey in Social Research Fourth Edition. Australia: Allen \& Unwin Pty Ltd.

Decenzo, David, A \& Stephen, P Robbins. (2002). Human Resource Management. (7th Ed). New York: John Wiley \& Sons, Inc.

Dessler, Gary. (2003). Human Resource Management (9th Ed). New Jersey: Prentice Hall. 
Griffin, Jill. (2005). Customer Loyalty: Menumbuhkan\&Mempertahankan Kesetiaan Pelanggan (Dwi Kartini Yahya, Penerjemah). Jakarta: Erlangga.

Hair, Joseph F, Jr, William C. Black, Barry J. Babbin, \& Rolph E. Anderson. (2010). Multivariate data analysis (7th edition). New Jersey: Pearson Prentice Hall.

Imamoglu, Salih Zeki. (2007). "An Empirical Analysis Concerning the User Acceptance of E-learning”. Journal of American Academy Business, Cambrige. Vol. 11 No.1. pp 132-137.

Indonesia Press Online Services. (2012). Internet Mobile Jadi Tren yang Tumbuh Pesat. http://www. iposnews.com/2012/06/07/ internet-mobile-jadi-tren-yangtumbuh-pesat/. (diakses pada tanggal 3 Oktober 2012).

Jiinpo Wu, Ray J. Tsai, Charlie C. Chen, \& Yachen Wu. (2006). “An Integrative Model to Predict the Continuance Use of Electronic Learning Systems: Hints for Teaching". International Journal on E-learning. Vol. 5 No.2. pp 287-302.

Ltifi, Moez \& Jamel-Eddine Gharbi. (2012). "E-satisfaction and E-loyalty of Costumer Shopping Online". Journal of Internet Banking and Commerce. Vol. 17 No.1. pp 1-20.

Mondy, R. Wayne. (2008). Manajemen Sumber Daya Manusia (Bayu Airlangga, penerjemah). Jakarta: Penerbit Erlangga.

Noe, Raymond, A. (2010). Employee Training and Development (5th Ed). New York: McGraw-Hill.

Mechinda, Panisa, Sirivat, Serirat \& Nak, Gulid. (2009). "An Examination of Tourists' Attitudinal and Behavioral Loyalty: Comparison between Domestic and International Tourists". Journal of Vacation
Marketing. Vol.15 No. 2. pp 129148.

Oliver, C., (1997). "Sustainable Competitive Advantage: Combining Institutional and Resources-based View". Strategic Management Journal. Vol.18 No.9. pp 697-713.

Packham, Gary, P. Jones, C. Miller \& B. Thomas. (2004). "E-learning and Retantion: Key Factors Influencing Student Withdrawal". Emerald Group Publishing Limited. Vol. 43 No.6/7. pp 335-342.

Rae, Leslie. (2000). Effective Planning in Training and Development. London: Kogan Page Limited.

Ribbink, Dina, Allard, C.R Van Riel Veronica Liljander, \& Sandra, Streukens. (2004). "Comfort Your Online Customer: quality, trust and loyalty on the internet”. Managing Service Quality. Vol. 14 No. 6. Pp 446-456.

Rosenberg, Mar, J. (2001). E-learning: Strategies for Delivering Knowledge in the Digital Age. United State of America: McGraw-Hill.

Rosenberg, Marc, J. (2006). Beyond E-learning. San Fransisco: Pfeiffer.

Sahadev, S, \& Purani, K. (2008). "Modelling the Consequances of e-service Quality”. Marketing Intelligence and Planning.Vol. 26 No. 6, pp 605-620.

Sekaran, Uma \& Roger, Bougie. (2011). Research Methods for Business: A sill Building Approach (5th Ed). United KinFgdom: John Wiley \& Sons Ltd.

Teimouri, Maliheh, Nour Mohamad Yaghoubi, \& Kazemi, Mehdi. (2012). "The Effect of Electronic Service Quality on Costumers Behavioral Intention”. International Journal of Marketing Studies. Vol.4 No.2. pp 179-187.

Vaugan, Kirsty \& Anna, MacVicar. (2004). 'Employees' Pre- 
implementation Usman, Husaini, \& Purnomo Setiady Akbar. (2006). Metodologi Penelitian Sosial. Jakarta: Bumi Aksara.

Venkatesh, Viswanath dan kawankawan. (2003). "User Acceptance of Information Technology Toward a Unified View". MIS Quaeterly. Vol. 27 No.3. pp 428-478.

Wan-Tzu, Wong \& Neng-Tang Norman Huang. (2011). "The Effect of E-learning System Service Quality and Users' Accepatance on Organizational Learning”. International Journal of Business and Information. Vol. 6 No. 2. pp 205-225.

Ya-Ching, Lee. (2006). "An Empirical Investigation Into Factors Influencing the Adoption of an E-learning System". Emerald Group Publishing Limited. Vol. 30 No. 5. Pp 517-541. 